\title{
SUPRAPUBIC LAPAROSCOPIC CHOLECYSTECTOMY: TECHNIQUE AND PRELIMINARY RESULTS
}

\author{
Colecistectomia laparoscópica suprapúbica: técnica e resultados preliminares \\ Leonardo Adolpho S. SALES, João Odilo G. PINTO, Carlos Eduardo F. QUEIROZ, \\ Marcelo CASTRO, Paulo Henrique F. DOURADO, Fernando Antonio S. PINHEIRO
}

From the Hospital Universitário Walter Cantídio, Faculdade de Medicina, Universidade Federal do Ceará (Walter Cantídio University Hospital, Federal University of Ceará, Fortaleza, CE, Brazil.

HEADINGS - Minimally invasive surgery. Cholecystectomy. Laparoscopy.
ABSTRACT - Background: The minimally invasive abdominal surgery has evolved to reduce portals, culminating with a single incision and natural orifice operation. However, these methods are still expensive, difficult to implement and with questionable aesthetic results. Aim: To present the standardization and preliminary results of a technique for performing laparoscopic suprapubic access by the principle which was called the Supra Pubic Endoscopic Surgery for cholecystectomy. Method: The average body mass index of patients, the mean operative time, clinical data of the postoperative complications and quality of life were prospectively studied. The operation incisions consisted of: A) umbilical for instrumental dissection and clipping; B) in the right groin for handling and gallbladder gripping; C) suprapubic for the camera. With the patient in reverse Trendelenburg and left lateral decubitus, the operation flew by the camera trocar in $\mathrm{C}$, proceeding with dissection and isolation of the biliary pedicle, identification of cystic duct and artery, with usual instrumentation. Transcystic intraoperative cholangiography was performed in all cases in which there were indications. The procedure was completed with clipping and sectioning of the cystic duct and artery, retrograde resection of the gallbladder and extracting it by the umbilical trocar incision under direct vision. Results: Thirty patients undergone this surgical procedure between March and June 2012 and were evaluated. The mean age was 40.7 years and the indications were typical biliary colic in 18 cases (60\%), cholecystitis in five cases (16.6 $\%)$, biliary pancreatitis in one case (3.3\%); polyp in three cases (10\%) and obstructive jaundice at three cases (10\%). The average body mass index was 27.8 (23.1-35.1) and surgical time ranged between 24 and 70 minutes. Conclusion: The technique proved to be feasible and safe, with no significant complications, and satisfactory cosmetic results.

\section{Correspondence:}

Leonardo Adolpho de Sá Sales

E-mail: leonardoadolpho@bol.com.br

Financial source: none

Conflicts of interest: none

Received for publication: 15/08/2013 Accepted for publication: 05/12/2012

DESCRTORES - Cirurgia minimamente invasiva. Colecistectomia. Laparoscopia. Técnica cirúrgica.
RESUMO - Racional: A cirurgia minimamente invasiva abdominal tem evoluído para redução dos portais, culminando com a por incisão única e a operação por orifícios naturais. Porém, estes métodos ainda são dispendiosos, de difícil execução e com resultados estéticos questionáveis. Objetivo: Apresentar a padronização e os resultados preliminares de uma técnica para realização de colecistectomia por acesso suprapúbico pelo princípio que foi chamado de Supra-Pubic Endoscopic Surgery para colecistectomia. Método: Foram pesquisados prospectivamente o índice de massa corporal médio dos pacientes, a média do tempo operatório e os dados clínicos do pós-operatório com vistas às complicações e qualidade de vida. A operação consistiu de incisão: A) umbilical para o instrumental de dissecção e clipagem; B) na região inguinal direita para manipulação e preensão da vesícula biliar; C) suprapúbica para a câmera. Com o paciente em proclive e decúbito lateral esquerdo, a operação transcorria com a câmera no trocarte C. Procediase a dissecção e isolamento do pedículo biliar, identificação de ducto e artéria císticas, utilizando instrumental habitual. Colangiografia transoperatória transcística era realizada em todos os casos em que havia indicação. O procedimento era concluído com a clipagem e secção do ducto e artéria cística, ressecção retrógrada da vesícula biliar e extração dela pelo trocarte na incisão umbilical, sob visão direta. Resultados: Foram avaliados 30 pacientes submetidos a esta modalidade cirúrgica entre março e junho de 2012. A média de idade foi de 40,7 anos e as indicações foram: cólica biliar típica em 18 casos (60\%); colecistite em cinco casos (16,6\%); pancreatite biliar em um caso (3,3\%); pólipo em três casos (10\%) e icterícia obstrutiva em três casos (10\%). O índice de massa corporal médio dos pacientes foi de 27,8 (23,1-35,1) e o tempo cirúrgico variou entre 24 e 70 minutos. Conclusão: A técnica mostrou-se segura e factível, não havendo complicações relevantes, e os resultados estéticos foram satisfatórios. 
INTRODUCTION

dvances in surgery have always been
marked by controversies between
conservative and innovative aspects. Paradigms fall and axioms once thought to be absolute true do not sustain themselves when faced with new concepts. Laparoscopic surgery represents the greatest example of this phenomenon. Erich Muhe in Germany performed the first laparoscopic cholecystectomies in 1985 and was followed by Philippe Mouret in Lyon, France, who added a video equipment to the laparoscopic procedure in $1987^{6}$. Since then, the videolaparoscopic techniques are considered one of the greatest revolutions in surgery, being the gold standard approach for most of the interventions on the digestive tract. Its advantages are widely accepted, and include the faster recovery as well as a better aesthetic result t,10.

More recently, the laparoscopic surgery has also been challenged by a new and really innovative approach called NOTES (Natural Orifice Transluminal Endoscopic Surgery) ${ }^{8}$. The idea of an operation performed without any skin incisions comes to break more paradigms. However some questions naturally came up ${ }^{5}$ : what are the real advantages?; are there any technical limitations?; are there reliable instruments to perform these operations?; is it a method that can be reproduced by the majority of surgeons?; is it cost-effective?

By the same time, other alternatives started to emerge: video-assisted surgery, minilaparoscopic instruments, robotic surgery, and, more recently, the SILS (Single Incision Laparoscopic Surgery), the latter being more rapidly and widely accepted when compared to NOTES, which reveled itself very unpractical. Many articles were published using SILS techniques, but as the method became more popular among surgeons, the technical difficulties started to appear ${ }^{1,9}$. The necessity of developing a whole new set of curved instruments and multichannel trocars made the procedures more expensive and complicated. Moreover, there's a need for specific training with the single port, and the larger incision increases the chances bleeding and of incisional hernias, which adversely affects the aesthetical results ${ }^{11}$.

The surgical technique proposed in this study is a viable option to contemplate the minimized surgical aggression and the better aesthetical result. The principles called SPES - Supra Pubic Endoscopic Surgery, consist in the laparoscopic removal of the gallbladder through the placement of three trocars placed on the umbilical region and lower suprapubic region (medial and lateral). Using the same available laparoscopic instruments, it can be easily reproduced with minimal learning curve.

The aim of this study was to evaluate the preliminary results of the first series of patients operated with this technique. Aspects of feasibility, surgical time, hospital stay, complications and patient satisfaction were analyzed.

\section{METHODS}

Between March and June 2012, a total of 30 patients with symptomatic gallbladder disease were enrolled for the opportunity to be submitted to the new technique of laparoscopic cholecystectomy using the suprapubic approach (SPES). The procedures were held by the same surgical team in the city of Fortaleza, CE, Brazil and the study was approved by the ethics committee of the Federal University of Ceará, Faculty of Medicine. Inclusion criteria were: aesthetical concerns, low surgical risk (ASA I or II) and elective operations. Patients with previous incisions on the upper abdomen were excluded as well as situations of urgent surgical indication or absence of consent by the patient. Cases with previous history of complicated biliary disease, such as cholecystitis, pancreatitis or choledocolithiasis, were not excluded if those conditions were fully treated and the patients have fully recovered.

\section{Surgical technique}

After general anesthesia, the patient was positioned in dorsal decubitus with the lower limbs in abduction. Spontaneous bladder emptying was done routinely. The surgeon standed between the patients' legs with the assistant on his left side (Figure 1). The initial incision was performed transumbilically and a subsequent pneumoperitoneum of $12 \mathrm{mmHg}$ was insufflated through a Veress needle puncture. At this site, the first trocar of $10 \mathrm{~mm}(A)$ was introduced for an initial camera position. The abdominal cavity was then inspected and the remaining two trocars could be clearly visualized during its insertions. The second trocar of $5 \mathrm{~mm}$ (B) was introduced at the right inguinal region, 1 to $2 \mathrm{~cm}$ above the inguinal ligament. From skin incision to the peritoneal penetration a very oblique trajectory was necessary to allow the internal trocar entrance to be placed many centimeters above, far away from the bladder and lateral to right inferior epigastric vessels. At this point, the gallbladder could be manipulated to finally determine if the suprapubic approach could be continued. The last and third 10 $\mathrm{mm}$ trocar $(C)$ was then placed through a skin incision on the suprapubic abdominal midline, 1 to $2 \mathrm{~cm}$ above the pubis and also making an oblique subcutaneous trajectory before entering the cavity many centimeters above (Figures 2 and 3). When present, previous scars were used as the site for the skin incisions.

The camera was moved to its permanent position on trocar $C$. The patient was kept on reverse Tredenlemburg and left lateral decubitus. Trocar 
A was used for dissection and clipping and trocar $B$ for manipulation and traction of the gallbladder (Figure 4). Dissection and identification of the biliary pedicle structures for the ligation of the cystic duct and artery were done in the usual fashion. Currently available instruments as hooks, graspers, mixters and marylands clamps were enough to perform the entire procedure. When indicated, a transoperatory, transcystic cholangiography was performed in all cases. After the retrograde resection of the gallbladder, its extraction could be directly visualized by simply keeping the camera at trocar $\mathrm{A}$ site.

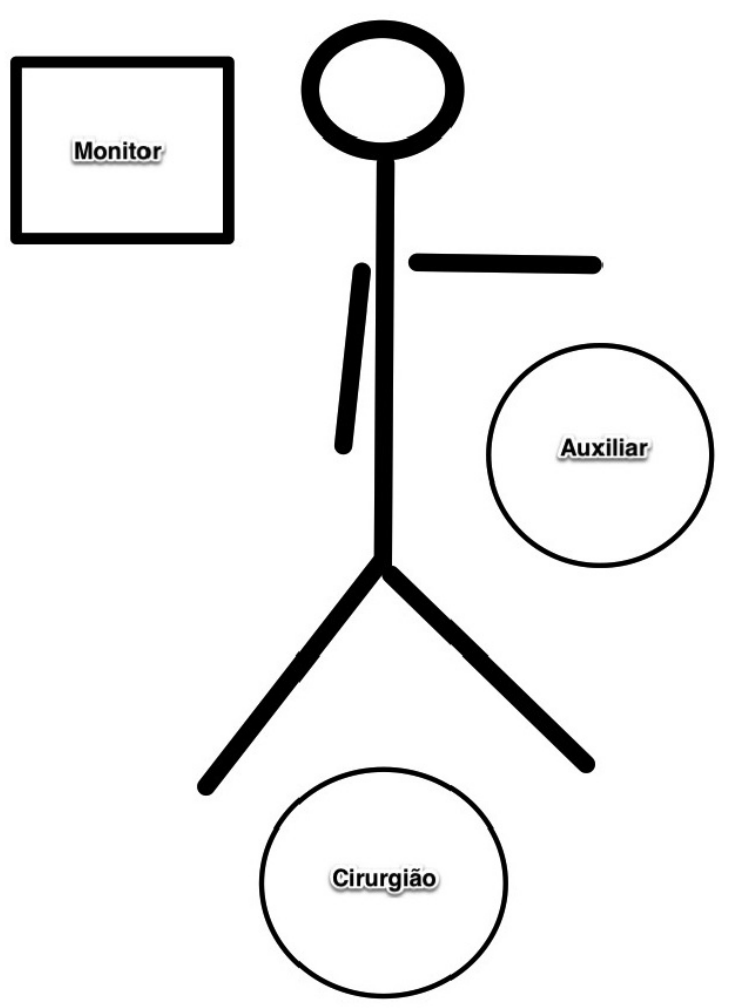

FIGURE 1 - Positioning of the patient and the surgical team

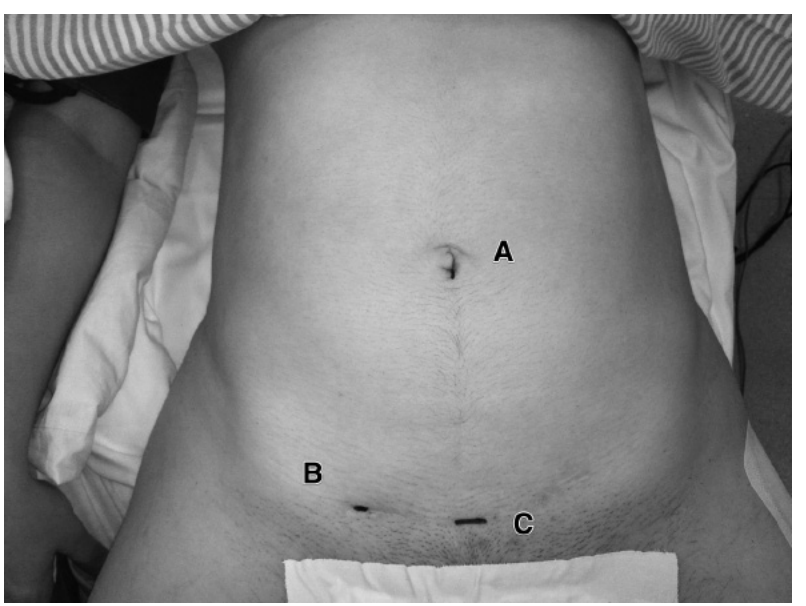

FIGURE 2 - Incision sites: A) used for the instrumental dissection and clipping; B) for handling and gripping the gallbladder; C) for camera

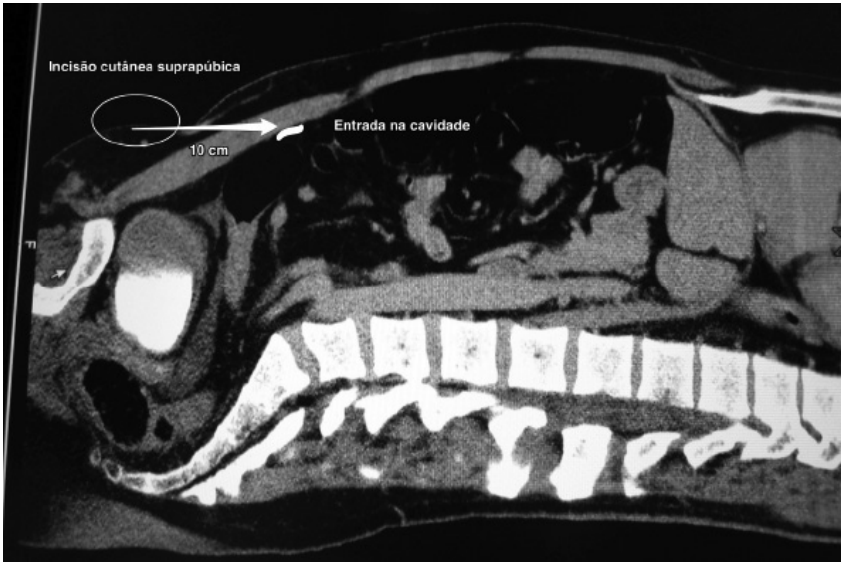

FIGURE 3 - Position to the introduction of the trocar into the cavity

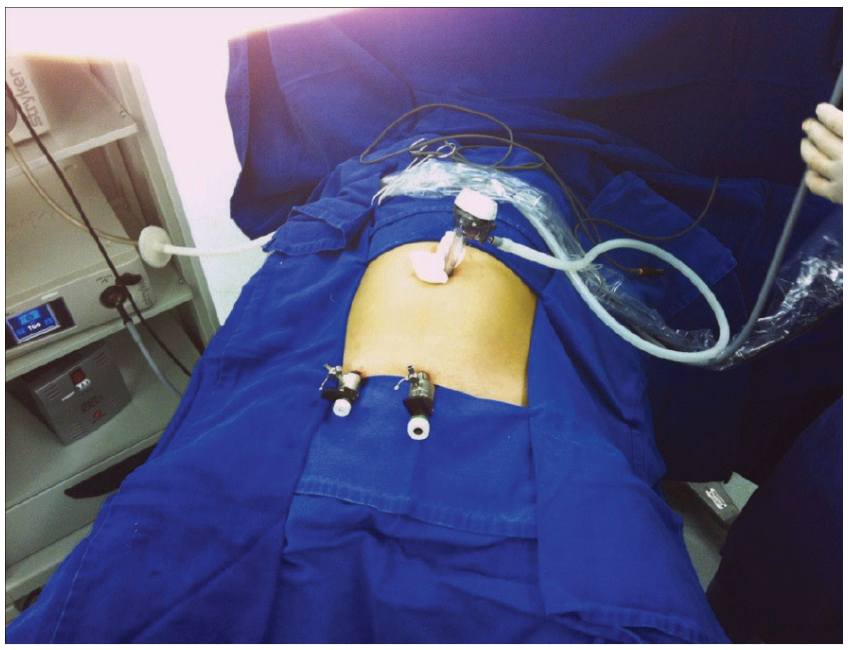

FIGURE 4 - Umbilical trocar for instrumental dissection and clipping

\section{RESULTS}

From the total of 30 patients, 28 were women and two men. The mean age was 40,7 years (24-63) and indications were: typical biliary colic in 18 cases (60\%); acute cholecystitis in five cases $(16,6 \%)$; biliary pancreatitis in one case (3,3\%); polyps in three cases $(10 \%)$ and gallstones associated to obstructive jaundice in three cases (10\%). The mean body mass index was $27,8(23,1-35,1)$. The mean operative time, counted from first skin incision to last skin suture was 40,7 minutes (24-70). The duration was longer in the first few patients of the series and in the cases where a transoperative cholangiography was performed $(n=13,43 \%)$. The placement of a fourth trocar of $5 \mathrm{~mm}$ was necessary in two patients due to technical difficulties in the first cases. All but one patient were discharged from the hospital on postoperative day one, the exception being a case diagnosed with choledocolithiasis that had to be sent to endoscopic treatment and was discharged on day two. There was no need for conversion to another approach, 
either traditional laparoscopy or open surgery, and there were no operative complications. Return to the routine activities could be accomplished in 15 days in all cases. The subjective manifestation of satisfaction with the operation results was positive for all patients.

\section{DISCUSSION}

In present time, the evolution of minimally invasive surgery through the development of new techniques that reduce or even don't use skin incisions (SILS and NOTES) are supported specially by its aesthetic advantages ${ }^{4,12}$. It is important to note, however, that those advances are not being made without risks and costs. The need for a whole set of new instruments and specific training with new learning curves imposes economic and technical costs that put more pressure on the medical systems and surgeons. Besides, by adding much complexity, the availability of the procedures becomes very reduced. Furthermore, it is still necessary to better evaluate and understand the real trade of these novel approaches. Are the complications acceptable? Is there really an aesthetical advantage in SILS regarding the parietal sequelae to the abdominal wall?

The SPES cholecystectomy proved to be a reproducible method ${ }^{3,5}$. It doesn't require instruments different from those already available for traditional laparoscopy (like trocars, graspers and clamps). It can be easily performed as a routine approach at any hospital, with any staff prepared for laparoscopy.

The dissection of the cystohepatic (Calot's) triangle and the retrograde removal of the gallbladder are not substantially more difficult because triangulation is guaranteed. For the surgeon, positioning during the procedure is comfortable and the method is fully compatible with the performance of transoperative cholangiography, adding more security. The absence of any incisions and instruments on the upper abdominal wall even makes the radiologic images more reliable.

It is important to note that the visualization of the upper abdominal cavity from a very low placed camera requires some adaptation, the first few cases requiring attention and caution. When technical difficulties are faced, an alternative help can be obtained by introducing the Veress needle on the right costal margin. It can give the extra traction needed to make some cases really easy to perform, and can be used as well for the transoperative cholangiography.

Naturally, the operative time was longer in the first cases, but early in the learning curve it matched the duration of traditional laparoscopic cholecystectomy. The absence of complications testifies the safety of this approach, which has the same hospital stay and return to activities when compared to standard and novel technique.

There is another advantage. The extraction of the gallbladder specimen through umbilical incision can be done easily with the camera on its operative position at the lower abdomen, without the need for switching trocars and without cumbersome mirror imaging. The presence of previous pelvic Pfannestiel scar, very common in Brazil, makes the esthetic benefit even more evident.

The idea of placing the laparoscopic trocars on the lower abdomen to improve the aesthetic result its not new $^{6}$. However, this is the first time that a greater series of patients is presented, showing favorable results and inviting for the wide acceptance of the method. Moreover, many other laparoscopic operations that take place on the upper abdomen can be executed in the same fashion (appendectomies, Nissen fundoplication, Heller myotomies, gastrectomies, etc), making this approach a good option for the treatment of various surgical conditions.

\section{CONCLUSION}

The technique proved to be feasible and safe, with no significant complications, and satisfactory cosmetic results.

\section{REFERENCES}

1. Arezzo A, Scozzari G, Famiglietti F, Passera R, Morino M: Is single-incision laparoscopic cholecystectomy safe? Results of a systematic review and meta-analysis. Surg Endosc 2013;

2. Flora ED, Wilson TG, Martin IJ, O'Rourke NA and Maddern GJ: A Review of Natural orifice translumenal endoscopic surgery (NOTES) for intra-abdominal surgery experimental models, techniques, and applicability to the clinical setting. Ann Surg 2008; 247:583-602.

3. Gerdes B, Gitei E, Akkermann O, Prasse-Badde J, Schmidt C Laparoscopic cholecystectomy without visible scar. Combined suprapubic and transumbilical approach: the "Minden cholecystectomy". Endoscopy 2009; 41(2):49-50.

4. Hagen ME, Wagner OJ, Thompson $K$, Jacobsen $G$, Spivack $A$, Wong B, Talamini M, Horgan S: Supra-Pubic Single Incision Cholecystectomy. J Gastrointest Surg 2010; 14:404-407.

5. Hu H, Zhu JF, Huang AH, Xin Y, Xu AA, Chen B: Covert Laparoscopic Cholecystectomy: A New Minimally Invasive Technique. Acta Med. Okayama 2011; 65(5):325-328.

6. Jr RW :The first laparoscopic cholecystectomy.JSLS 2001; 5(1):89-94.

7. Lima GJ, Silva AL, Leite RF, Abras GM, Castro EG, Pires LJ: Transumbilical laparoscopic assisted appendectomy compared with laparoscopic and laparotomic approaches in acute appendicitis. Arq Bras Cir Dig 2012; 25(1):2-8.

8. Marescaux M, Dallemagne B, Perretta S, Wattiez A, Mutter D, Coumaros D: Surgery Without Scars:Report of Transluminal Cholecystectomy in a Human Being. Arch Surg. 2007;142(9):823-827.

9. Saad S, Strassel V, Sauerland S: Randomized clinical trial of single-port, minilaparoscopic and conventional laparoscopic cholecystectomy. Br J Surg 2013; 100(3):339-49.

10. Toneto MG, Mohr CC, Lopes MHI: From great surgical incisions to laparoscopic cholecystectomy: reflection on the impact of new technologies. Scientia Medica 2007; 17(1):31-35.

11. Trastulli S, Cirocchi R, Desiderio J, Guarino S, Santoro A, Parisi A, Noya G, Boselli C: Systematic review and meta-analysis of randomized clinical trials comparing single-incision versus conventional laparoscopic cholecystectomy.Br J Surg 2013; 100(2):191-208.

12. Wood SG, Panait L, Duffy AJ, Bell RL, Roberts KE: Complications of Transvaginal Natural Orifice Transluminal Endoscopic Surgery: A Series of 102 Patients.Ann Surg 2013. 